\title{
Amorphous Silicon Single-Junction Thin-Film Solar Cell Exceeding 10\% Efficiency by Design Optimization
}

\author{
Mohammed Ikbal Kabir, ${ }^{1}$ Seyed A. Shahahmadi, ${ }^{2}$ Victor Lim, ${ }^{2}$ Saleem Zaidi, ${ }^{2}$ \\ Kamaruzzaman Sopian, ${ }^{2}$ and Nowshad Amin'1, 2,3 \\ ${ }^{1}$ Department of Electrical, Electronic and Systems Engineering, Faculty of Engineering and Built Environment, \\ The National University of Malaysia, Selangor, 43600 UKM, Bangi, Malaysia \\ ${ }^{2}$ Solar Energy Research Institute (SERI), The National University of Malaysia, Selangor, 43600 UKM, Bangi, Malaysia \\ ${ }^{3}$ CEREM, College of Engineering, King Saud University, Riyadh 11421, Saudi Arabia
}

Correspondence should be addressed to Nowshad Amin, nowshadamin@yahoo.com

Received 28 July 2012; Revised 17 September 2012; Accepted 1 October 2012

Academic Editor: David Lee Phillips

Copyright (C) 2012 Mohammed Ikbal Kabir et al. This is an open access article distributed under the Creative Commons Attribution License, which permits unrestricted use, distribution, and reproduction in any medium, provided the original work is properly cited.

\begin{abstract}
The conversion efficiency of a solar cell can substantially be increased by improved material properties and associated designs. At first, this study has adopted AMPS-1D (analysis of microelectronic and photonic structures) simulation technique to design and optimize the cell parameters prior to fabrication, where the optimum design parameters can be validated. Solar cells of single junction based on hydrogenated amorphous silicon (a-Si:H) have been analyzed by using AMPS-1D simulator. The investigation has been made based on important model parameters such as thickness, doping concentrations, bandgap, and operating temperature and so forth. The efficiency of single junction a-Si:H can be achieved as high as over 19\% after parametric optimization in the simulation, which might seem unrealistic with presently available technologies. Therefore, the numerically designed and optimized a-SiC:H/a-SiC:H-buffer/a-Si:H/a-Si:H solar cells have been fabricated by using PECVD (plasma-enhanced chemical vapor deposition), where the best initial conversion efficiency of $10.02 \%$ has been achieved $\left(V_{\mathrm{oc}}=0.88 \mathrm{~V}, J_{\mathrm{sc}}=15.57 \mathrm{~mA} / \mathrm{cm}^{2}\right.$ and $\mathrm{FF}=0.73)$ for a small area cell $\left(0.086 \mathrm{~cm}^{2}\right)$. The quantum efficiency $(\mathrm{QE})$ characteristic shows the cell's better spectral response in the wavelength range of $400 \mathrm{~nm}-650 \mathrm{~nm}$, which proves it to be a potential candidate as the middle cell in a-Si-based multijunction structures.
\end{abstract}

\section{Introduction}

The performance of solar photovoltaic cells depends on its design, material properties, and fabrication technology. Photovoltaic (PV) researchers present improved cells over the period of time, although the overall process is quite complex, expensive, and time consuming. Numerical simulation is the best approach for solar cell researchers, which help to find out an optimized structure with good fitted parameters. As a result fabrication complexity, costs, and time reduce significantly. The major objectives of numerical modeling and simulation in solar cell research are testing the validity of proposed physical structures, geometry on cell performance, and fitting of modeling output to experimental results. The numerical modeling has become indispensable tools for designing a high-efficiency solar cell. Numerical modeling is increasingly used to obtain insight into the details of the physical operation of thin-film solar cells. Over the years, several modeling tools specific to thin-film PV devices have been developed. A number of these tools have been reached in a mature status and are available to the PV community. A driving force for the development is the complicated structure of thin-film PV devices. The internal optical and electronic operation of these cells is not possible if there is a lack of precise modeling. Numerical modeling is necessary for the realistic description of thin-film PV devices. On the other hand, analytic models have been used to improve understanding of the operation of the cells and to 
provide a proper guidance for their design since the earliest time of modern solar cells. The analytical descriptions are possible only under certain assumptions and simplifications.

Hydrogenated amorphous silicon (hereafter, a-Si:H) thin film is a good optoelectronic material candidate for solar cell applications as it has high optical absorption coefficient $\left(>10^{5} \mathrm{~cm}^{-1}\right)$, adjustable bandgap, and low temperature deposition capability. The optical bandgap up to $1.7 \mathrm{eV}$ lies near the energy at which high solar energy conversion efficiencies are expected. The bandgap of a-Si:H can be tuned from 1.6 to $1.8 \mathrm{eV}$. The conversion efficiency of hydrogenated amorphous silicon (a-Si:H) single-junction thin-film solar cells has gradually been improved from $2.4 \%$ [1] to $10.1 \%$ [2]. The hydrogenated amorphous silicon (a-Si:H) solar cell progress has been started from the invention of first Schottky device with an efficiency of $2.4 \%$ by Carlson and Wronski [1] and Kabir et al. [3]. However, the first great breakthrough came with the growth of amorphous silicon from silane $\left(\mathrm{SiH}_{4}\right)$ plasma by Chittick et al. [4]. And the second major breakthrough was the substitutional doping by phosphine $\left(\mathrm{PH}_{3}\right)$ or diborane $\left(\mathrm{B}_{2} \mathrm{H}_{6}\right)$ to the plasma during growth of n-type and p-type materials [5]. These outstanding properties of a-Si:H as an amorphous semiconductor generated enormous interest and started a large research effort worldwide [6]. Materials quality, device structure, and deposition technique are very important for improving solar cell efficiency [3]. There are several fabrication methods such as PECVD (RF, VHF, and Microwave), hot-wire CVD, photo CVD, sputtering, ECR CVD, and PBD downstream have been applied for improving cell performance [3, 7]. Among these methods, PECVD is the most successful method for the fabrication of a-Si:H solar cells that has been used for the fabrication of single-junction a-Si:H solar cells.

The efficiency of solar cell is the resultant outcome of its open circuit voltage $\left(V_{\mathrm{oc}}\right)$, short circuit current $\left(J_{\mathrm{sc}}\right)$, and fill factor (FF). For improving the efficiency of a solar cell, it is necessary to upgrade the above-mentioned parameters. In order to improve the device performance of a-Si:H solar cells, emphasis should be given mainly on higher short circuit current $\left(J_{\mathrm{sc}}\right)$ by developing light trapping scheme [8] and another one is to improve $V_{\text {oc }}$ by applying new device design techniques with different a-Si alloys. A new device structure has been introduced by using hydrogenated microcrystalline silicon ( $\mu$ c-Si:H) as an active layer for solar cells in 1994 by the IMT group at the University of Neuchâtel in Switzerland [9]. They achieved an initial efficiency of $4.6 \%$ for a $\mu \mathrm{c}-\mathrm{Si}: \mathrm{H}$ $\mathrm{p}-\mathrm{i}-\mathrm{n}$ single-junction solar cell with almost no light-induced degradation. Meanwhile, they developed the so-called "micromorph" a-Si/ $\mu \mathrm{c}-\mathrm{Si}$ tandem solar cell concept and achieved 12\% stabilized efficiency [10]. The advance light trapping system-intermediate reflector in micromorph solar cell reduced light-induced degradation of about 1.64\% [11]. Saito et al. (2005) presented a-Si:H/ $\mu \mathrm{c}-\mathrm{Si}: \mathrm{H} / \mu \mathrm{c}-\mathrm{Si}: \mathrm{H}$ triplejunction solar cells with initial efficiency of $13.1 \%$ and lightinduced degradation about 7.2\% [12]. Many other attempts were taken by several research groups for improving $V_{\mathrm{oc}}$, such as applying wide bandgap window layers (a-SiC: $\mathrm{H}, \mu \mathrm{c}-$ $\mathrm{SiO}: \mathrm{H}$, nc-Si:H, etc.) in a-Si solar cells and inserting buffer layers at $\mathrm{p} / \mathrm{i}$ and $\mathrm{i} / \mathrm{n}$ interfaces $[13,14]$. The structure of aSiC:H/a-SiC:H-buffer/a-Si:H/a-Si:H single-junction amorphous silicon thin-film solar cell model has been designed and optimized and finally fabricated according to the best design achieved in numerical simulation to validate it.

\section{Design and Optimization}

Thin-film hydrogenated amorphous silicon (a-Si:H) singlejunction solar cell model has been designed and analyzed for exploring optimized structure for higher stabilized efficiency by using analysis of microelectronic and photonic structures (AMPS-1D) device simulator [15] which is shown in Figure 1. The conversion efficiency of a solar cell can be increased significantly with the improvement of materials properties and subsequently the designs and structures of the cell. An intrinsic absorber layer (a-Si:H) is enclosed between a p-type (a-SiC:H) and an n-type doped layer (a$\mathrm{Si}: \mathrm{H})$. The p-layer functions as window layer through which the light enters. Photons that are absorbed in the i-layer create an electron-hole pair. The electric field induced across the i-layer by the $\mathrm{p}$ - and n-layers causes the electrons to drift towards the n-layer and the holes towards the p-layer. At the doped layers, the charge carriers are collected by electrical contacts and contribute to the output power of the solar cell. In the device modeling, wide bandgap a-SiC:H is used as p-doped window layer to reduce absorption losses. Moreover, $V_{\mathrm{oc}}$ also increases for its wider bandgap. It is well known that $V_{\text {oc }}$ is sensitive to p-layer and p/i interface. As optical absorption at the p-layer limits $J_{\mathrm{sc}}$, wider optical gap material is always desired for improving $J_{\text {sc }}[16]$. The p-type graded a-SiC:H buffer layer was used to mitigate the $\mathrm{p} / \mathrm{i}$ interface effect which has a great influence on $V_{\mathrm{oc}}$ [17]. The design parameters have been adopted from some standard references (AMPS-1D) to investigate the variation of efficiency, $V_{\mathrm{oc}}, J_{\mathrm{sc}}$, and FF with the variation of thickness, bandgap, doping concentrations of $\mathrm{p}$ - and n-layers, and the dependence of efficiency on operating temperature. The values of different material parameters fed into AMPS-1D are shown in Tables 1 and 2.

The front TCO $\left(\mathrm{SnO}_{2}: \mathrm{F}\right)$ has been applied for reducing reflection loss. The effect of $\mathrm{ZnO}: \mathrm{B}$ along with metal contact $(\mathrm{Ag} / \mathrm{Al})$ was used to reduce the transmission loss through the back contact. The front and back TCO layers should have low electrical resistive and high optical transmittance in the visible wavelength range. Silver is inserted as back contact for its low resistivity $\left(2 \times 10^{-6} \Omega-\mathrm{cm}\right)$ to reduce the reflection losses through all layers. To increase the $J_{\mathrm{sc}}$, the low resistive $\left(2.6 \times 10^{-2} \Omega-\mathrm{cm}\right)$ and high optical transparent $\mathrm{ZnO}: \mathrm{B}$ layer is applied between n-layer and Ag as transparent back contact. However, $\mathrm{ZnO} / \mathrm{Ag}$ has the capability to overcome the adhesion problem between a-Si and metal contact [18].

2.1. Performance Analysis of a-Si:H Solar Cell. In a-Si-based solar cells, i-layer thickness optimization is one of the fundamental factors which influence the reduction of material costs and improve collection efficiency. The multijunction solar cells utilize solar spectrum effectively with thinner 


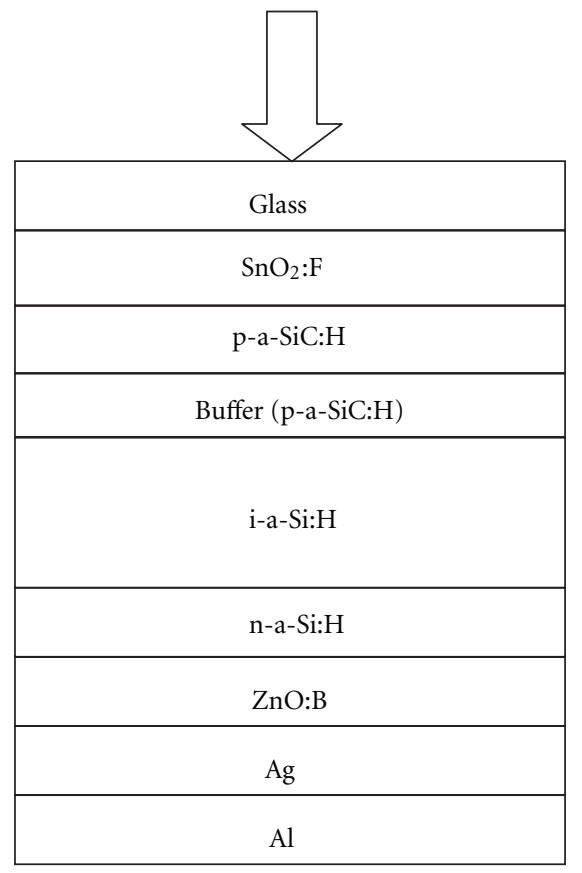

Figure 1: Schematic view of a-Si:H single-junction solar cell.

TABLE 1: The input parameters used in modeling the single-junction a-Si: $\mathrm{H}$ solar cell.

\begin{tabular}{|c|c|c|c|c|c|c|}
\hline Material/parameters & $\mathrm{SnO}_{2}: \mathrm{F}$ & $\begin{array}{l}\text { p-layer } \\
\text { a-SiC:H }\end{array}$ & $\begin{array}{l}\text { p- (buffer) layer } \\
\text { a-SiC:H }\end{array}$ & $\begin{array}{l}\text { i-layer } \\
\text { a-Si:H }\end{array}$ & $\begin{array}{l}\text { n-layer } \\
\text { a-Si:H }\end{array}$ & $\mathrm{ZnO}: \mathrm{B}$ \\
\hline$W(\mathrm{~nm})$ & $50-150$ & $10-20$ & $2-9$ & $100-1300$ & $15-30$ & $50-200$ \\
\hline$\varepsilon_{r}$ & 9 & 11.9 & 11.9 & 11.9 & 11.9 & 9 \\
\hline$\mu_{n}\left(\mathrm{~cm}^{2} / \mathrm{Vs}\right)$ & 60 & 20.0 & 20.0 & 20.0 & 20.0 & 33 \\
\hline$\mu_{p}\left(\mathrm{~cm}^{2} / \mathrm{Vs}\right)$ & 6 & 2.0 & 2.0 & 2.0 & 2.0 & 8 \\
\hline$N_{a}\left(\mathrm{~cm}^{-3}\right)$ & $1.3 \times 10^{19}$ & $3.0 \times 10^{18}$ & $6.0 \times 10^{18}$ & - & - & - \\
\hline$N_{d}\left(\mathrm{~cm}^{-3}\right)$ & - & - & - & - & $8.0 \times 10^{19}$ & $8.0 \times 10^{18}$ \\
\hline$E_{g}(\mathrm{eV})$ & 3.7 & 1.9 & 1.9 & $1.65-1.95$ & 1.75 & 3.3 \\
\hline$N_{c}\left(\mathrm{~cm}^{-3}\right)$ & $2.2 \times 10^{18}$ & $2.5 \times 10^{20}$ & $2.5 \times 10^{20}$ & $2.5 \times 10^{20}$ & $2.5 \times 10^{20}$ & $2.2 \times 10^{18}$ \\
\hline$N_{v}\left(\mathrm{~cm}^{-3}\right)$ & $1.8 \times 10^{19}$ & $2.5 \times 10^{20}$ & $2.5 \times 10^{20}$ & $2.5 \times 10^{20}$ & $2.5 \times 10^{20}$ & $1.8 \times 10^{19}$ \\
\hline$\chi(\mathrm{eV})$ & 4.8 & 4.0 & 3.8 & 4.0 & 3.8 & 4.5 \\
\hline
\end{tabular}

TABLE 2: General layer parameters.

\begin{tabular}{|c|c|c|}
\hline Parameters & Front contact & Back contact \\
\hline Barrier height $\left(\varphi_{\mathrm{bo}} / \varphi_{\mathrm{bL}}\right)$ & $\mathrm{PHIBO}=1.45 \mathrm{eV}$ & PHIBL $=0.08 \mathrm{eV}$ \\
\hline $\begin{array}{l}\text { Electron recombination } \\
\text { velocity }\end{array}$ & $\mathrm{SNO}=1 \times 10^{7} \mathrm{~cm} / \mathrm{s}$ & $\mathrm{SLN}=1 \times 10^{7} \mathrm{~cm} / \mathrm{s}$ \\
\hline $\begin{array}{l}\text { Hole recombination } \\
\text { velocity }\end{array}$ & $\mathrm{SPO}=1 \times 10^{7} \mathrm{~cm} / \mathrm{s}$ & $\mathrm{SPL}=1 \times 10^{7} \mathrm{~cm} / \mathrm{s}$ \\
\hline Reflection coefficient & $\mathrm{RF}=0.02$ & $\mathrm{RB}=0.8$ \\
\hline
\end{tabular}

absorber layers in different component cells and minimize recombination generation losses. Thus, the multijunction solar cell has a good impact on improving output voltage [19]. Electrons and holes generated in doped layers usually do not contribute to the photocurrent for their short life time. In p-i-n single-junction solar cell, p-layer should be as thin as possible to allow maximum light into the following layers. To find the optimum structure, the i-layer thickness has been varied from 100 to $1300 \mathrm{~nm}$, and the highest efficiency of $19.62 \%$ has been obtained at a i -layer thickness of $500 \mathrm{~nm}$ which is shown in Figure 2. A similar result has been observed in previous work [20]. In this work, the optimized intrinsic layer thickness $(500 \mathrm{~nm})$ reduced significantly compared with other finding- $700 \mathrm{~nm}$ [19], $600 \mathrm{~nm}$ [21], and $840 \mathrm{~nm}$ [22], respectively. FF and $V_{\mathrm{oc}}$ gradually decreased with the increase of i-layer thickness. The substantial fall in $V_{\mathrm{oc}}$ with the increase of i-layer thickness can possibly correlate to the associated increase of defect densities. Higher defect densities affect the electric field and carrier collection, eventually yielding in poor $V_{\text {oc }}$ [23]. This decrease in $V_{\text {oc }}$ might be averted with the introduction of a wide bandgap buffer layer, which reduces shunt resistance and prevents leakage current through the $\mathrm{p} / \mathrm{i}$ 

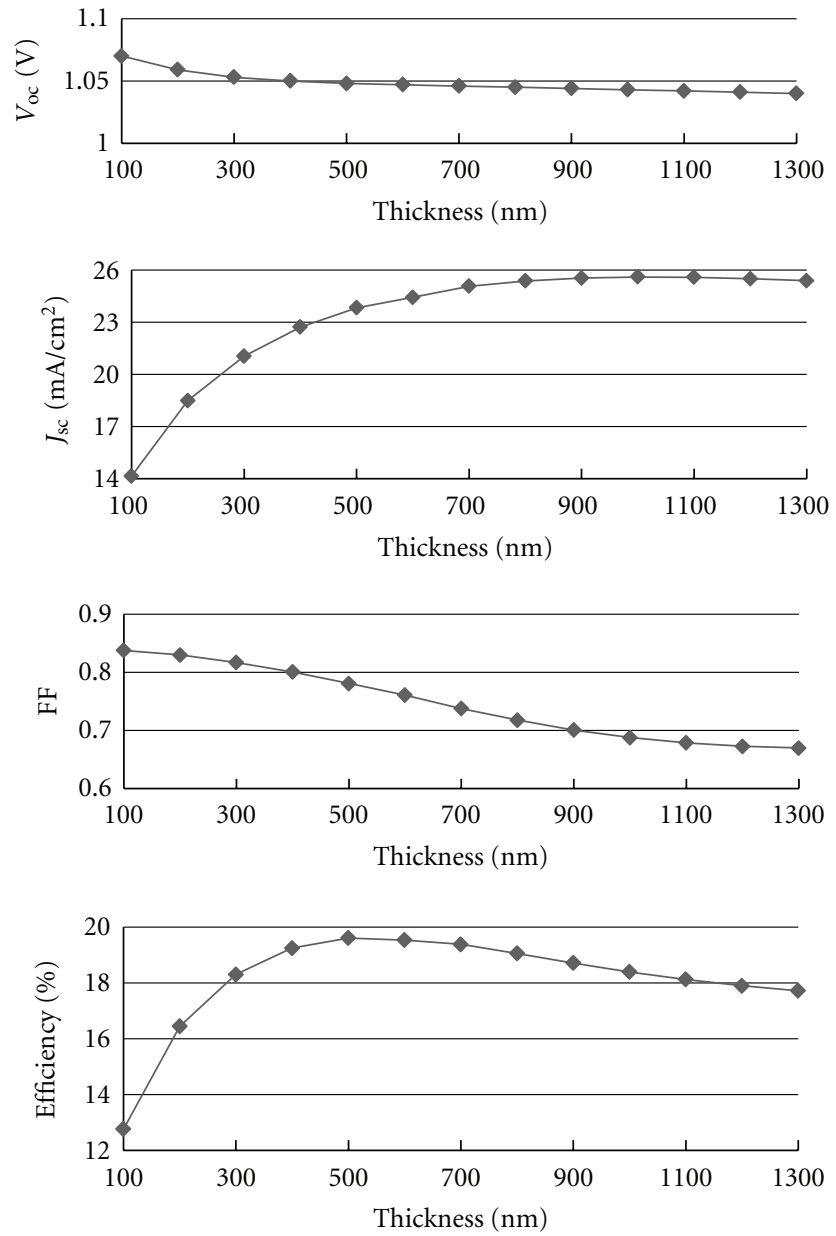

FIGURE 2: Photovoltaic characteristics for various absorber layer (aSi:H) thickness.

interface and $\mathrm{i} / \mathrm{n}$ interface [24]. $J_{\mathrm{sc}}$ monotonically increased up to $800 \mathrm{~nm}$, and then it saturates.

2.2. Optimization of a-Si:H Absorber Layer Bandgap. The energy of incident light gradually decreases with the increase of absorber thickness. The high energetic photon will be absorbed in top absorber layer. Therefore, bandgap can be gradually decreased for successive absorber layers in multijunction configuration. To optimize the bandgap of a-Si:H single-junction solar cells for middle cell of triple junction configuration, bandgap has been varied from 1.65 to $1.95 \mathrm{eV}$. Figure 3 represents the variation of efficiency with the change of bandgap of a-Si:H layer. The optimum bandgap has been observed at $1.75 \mathrm{eV}$ which corresponds to the maximum efficiency of $19.62 \%$. The intrinsic absorber layer optimum bandgap of $1.7 \mathrm{eV}$ [25] and $1.75 \mathrm{eV}$ [26] has been used in top cell of micromorph a-Si:H/ $\mu$ c-Si:H solar cell configuration and in a single-junction a-Si solar cell, respectively.

2.3. Effect of Operating Temperature on Cell Performance. Solar cell performance generally decreases with increasing

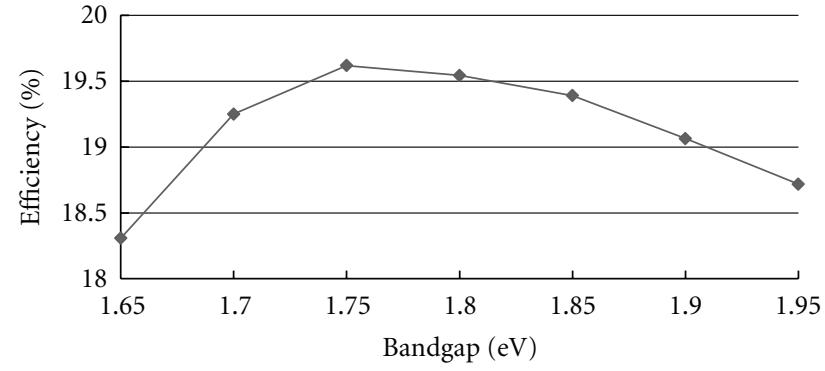

FIGURE 3: Effect of i-layer bandgap on cell performance.

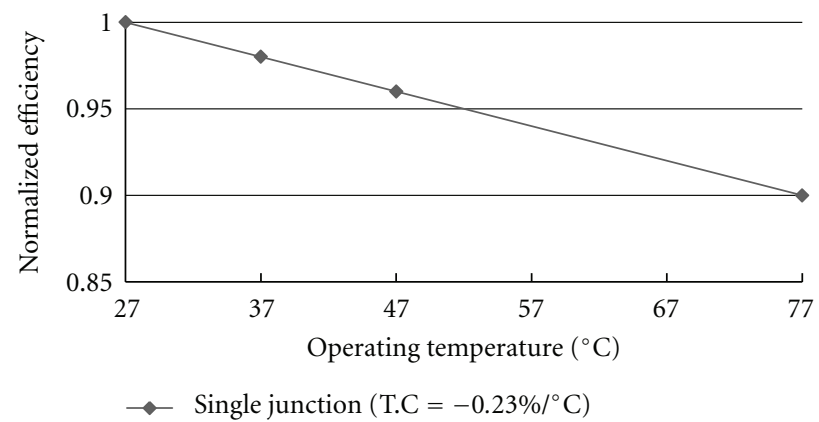

FIgURE 4: Operating temperature gradient.

temperature, mainly due to increased internal carrier recombination rates, caused by increased carrier concentrations. The other performance parameters such as open-circuit voltage $\left(V_{\mathrm{oc}}\right)$, short-circuit current $\left(J_{\mathrm{sc}}\right)$, and fill factor $(\mathrm{FF})$ are also temperature dependent. $V_{\text {oc }}$, and, FF decrease with temperature and $J_{\text {sc }}$ increases slightly with $T$. The rate of decrease of $V_{\mathrm{oc}}$ with temperature is controlled by the bandgap energy $\left(E_{g}\right)$, shunt resistance $\left(R_{\mathrm{sh}}\right)$, and its rate of change with $T$. Finally temperature effects on solar cell decrease the efficiency. This general temperature dependence of solar cells has been studied by different research groups [27-29] but the light-induced degradation effect of amorphous silicon $(\mathrm{a}-\mathrm{Si}: \mathrm{H})$ has been observed by Staebler and Wronski [30] which leads to decreased efficiency of cell with the increase of light exposure, and still it is a crucial problem for amorphous silicon solar cell. So there is a need to investigate the stability in efficiency of amorphous silicon solar cells for practical operation part but in theoretical study temperature coefficient is the only measure to predict how stable the cell efficiency is. Figure 4 shows that the temperature coefficient of the simulated single-junction amorphous silicon solar cell is $-0.23 \% /{ }^{\circ} \mathrm{C}$ which will be better in stability of efficiency for practical operation.

\section{Fabrication of the Optimized a-Si:H Single-Junction Thin-Film Solar Cells}

The designed and optimized a-SiC:H/a-SiC:H-buffer/aSi:H/a-Si:H single-junction thin-film solar cells have been fabricated for high efficiency by using PECVD. The $\mathrm{p}-\mathrm{i}-$ $\mathrm{n}$ amorphous silicon solar cells with an area of $0.086 \mathrm{~cm}^{2}$ 
TABLe 3: a-Si:H films deposition parameters.

\begin{tabular}{|c|c|c|c|c|c|c|c|c|c|c|c|}
\hline \multirow{2}{*}{ Layer } & \multirow{2}{*}{ Material } & \multirow{2}{*}{ PECVD } & \multicolumn{5}{|c|}{ Flow rate $(\mathrm{sccm})$} & \multirow{2}{*}{ Pressure $(\mathrm{Pa})$} & \multirow{2}{*}{$\begin{array}{l}\text { Power density } \\
\left(\mathrm{mW} / \mathrm{cm}^{2}\right)\end{array}$} & \multirow{2}{*}{ Sub. temp. $\left({ }^{\circ} \mathrm{C}\right)$} & \multirow{2}{*}{ Thickness (nm) } \\
\hline & & & $\mathrm{SiH}_{4}$ & MMS & $\mathrm{H}_{2}$ & $\mathrm{~B}_{2} \mathrm{H}_{6}$ & $\mathrm{PH}_{3}$ & & & & \\
\hline $\mathrm{p}$ & $\mathrm{a}-\mathrm{SiC}: \mathrm{H}$ & $\mathrm{RF}$ & 6 & 4 & 140 & 10 & - & 70 & 130 & 200 & 18 \\
\hline Buffer & $\mathrm{a}-\mathrm{SiC}: \mathrm{H}$ & $\mathrm{RF}$ & 6 & 4 & 140 & - & - & 70 & 130 & 200 & 2 \\
\hline $\mathrm{i}$ & $\mathrm{a}-\mathrm{Si}: \mathrm{H}$ & VHF & 5 & - & 45 & 一 & - & 50 & 130 & 200 & 500 \\
\hline $\mathrm{n}$ & $\mathrm{a}-\mathrm{Si}: \mathrm{H}$ & $\mathrm{RF}$ & 5 & - & - & - & 2.5 & 50 & 80 & 200 & 20 \\
\hline
\end{tabular}

MMS: monomethylsilane.

$\mathrm{B}_{2} \mathrm{H}_{6}$ and $\mathrm{PH}_{3}: 1 \% \mathrm{H}_{2}$ diluted.

TABLE 4: ZnO films deposition parameters.

\begin{tabular}{lcccccc}
\hline \multirow{2}{*}{ Layer } & \multicolumn{3}{c}{ Flow rate $(\mathrm{mmol} / \mathrm{min})$} & Pressure & Heater temp. $\left({ }^{\circ} \mathrm{C}\right)$ & Time (hour) \\
& $\mathrm{H}_{2} \mathrm{O}$ & $\mathrm{DEZ}$ & $\mathrm{B}_{2} \mathrm{H}_{6}$ & Thickness $(\mathrm{nm})$ \\
\hline $\mathrm{ZnO}: \mathrm{B}$ & 200 & 70 & 0.54 & 3 Torr & 158 & 4.0 \\
\hline
\end{tabular}

DEZ: diethylzinc.

TABLE 5: p-i-n a-Si:H solar cells performance.

\begin{tabular}{lcccc}
\hline Sample ID number & $\begin{array}{c}V_{\text {oc }} \\
(\mathrm{V})\end{array}$ & $\begin{array}{c}J_{\mathrm{sc}} \\
\left(\mathrm{mA} / \mathrm{cm}^{2}\right)\end{array}$ & FF & $\begin{array}{c}\text { Eff. } \\
(\%)\end{array}$ \\
\hline 110308-2-A01 & 0.881 & 15.16 & 0.734 & 9.81 \\
110308-2-A02 & 0.884 & 15.43 & 0.729 & 9.95 \\
110308-2-A03 & 0.884 & 15.50 & 0.728 & 9.98 \\
110308-2-A04 & 0.884 & 15.42 & 0.727 & 9.91 \\
110308-2-A05 & 0.881 & 15.10 & 0.730 & 9.72 \\
110308-2-A06 & 0.876 & 15.25 & 0.734 & 9.81 \\
110308-2-A07 & 0.880 & 15.46 & 0.731 & 9.95 \\
110308-2-A08 & $\mathbf{0 . 8 8 1}$ & $\mathbf{1 5 . 5 7}$ & $\mathbf{0 . 7 3 0}$ & $\mathbf{1 0 . 0 2}$ \\
110308-2-A09 & 0.882 & 15.45 & 0.731 & 9.96 \\
110308-2-A10 & 0.878 & 15.03 & 0.737 & 9.74 \\
\hline Average & 0.881 & 15.34 & 0.731 & 9.88 \\
\hline
\end{tabular}

have been fabricated on top of the $\mathrm{SnO}_{2}: \mathrm{F}$ coated glass (Asahi U-type glass) substrates. The structure of the fabricated cells is glass $/ \mathrm{SnO}_{2}: \mathrm{F} / \mathrm{p}$-a-SiC:H $(18 \mathrm{~nm}) / \mathrm{p}$-gradedbuffer $(2 \mathrm{~nm}) / \mathrm{i}-\mathrm{a}-\mathrm{Si}: \mathrm{H}(500 \mathrm{~nm}) / \mathrm{n}-\mathrm{a}-\mathrm{Si}: \mathrm{H}(20 \mathrm{~nm}) / \mathrm{ZnO}: \mathrm{B}$ $(70 \mathrm{~nm}) / \mathrm{Ag}(60 \mathrm{~nm}) / \mathrm{Al}(200 \mathrm{~nm})$, which is shown in Figure 1. The deposition sequence started from front TCO $\mathrm{SnO}_{2}: \mathrm{F}$ on Asahi U-type glass, which is commercially available in market. The doped layers ( $\mathrm{p}$ - and n-layers) have been deposited using 13.65 MHz RF-PECVD. The low hydrogen-diluted boron (B) graded bandgap p-a-SiC:H (LDgraded $\mathrm{p}-\mathrm{a}-\mathrm{SiC}: \mathrm{H}$ ) is formed by the sudden stoppage of the mass flow controller for the $\mathrm{B}$ source, that is, $\mathrm{B}_{2} \mathrm{H}_{6}$, during the deposition of the p-a-SiC:H window layer with RF-PECVD. Intrinsic a-Si:H films have been prepared using a capacitively coupled parallel plate VHF-PECVD system at a substrate temperature of around $200^{\circ} \mathrm{C}$. The plasmaexcitation frequency of the system has been set at $60 \mathrm{MHz}$. The MMS flow rates were $4 \mathrm{sccm}$, whereas the $\mathrm{H}_{2}$ flow rates can be changed from 45 to $140 \mathrm{sccm}$. $\mathrm{ZnO}: \mathrm{B}$ has been deposited using MOCVD technique. When a-Si:H

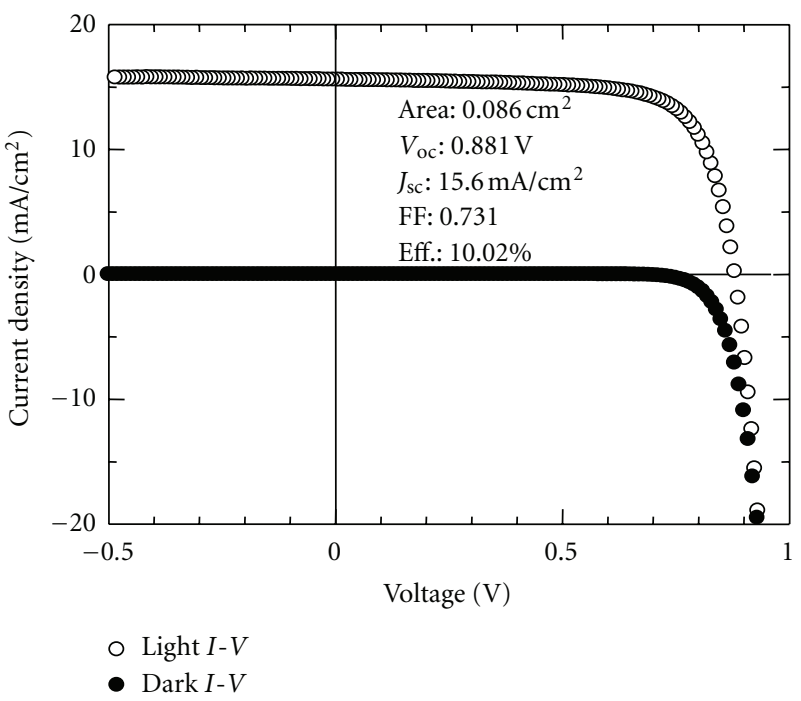

FIGURE 5: Photo- and dark $I-V$ characteristics of the p-i-n solar cell.

layer deposition has been completed, the samples have been removed from the PECVD. And final contact of $\mathrm{Ag} / \mathrm{Al}$ has been completed by thermal evaporation. Tables 3 and 4 show the deposition parameters for various layers. In this process, ten single-junction a-Si:H solar cells have been fabricated, and the result is presented in Table 5.

3.1. Solar Cell Performance of Optimized Structure. Both photo- and dark $I-V$ characteristics for the fabricated solar cell have been measured at $25^{\circ} \mathrm{C}$ under 1-sun (AM 1.5, $100 \mathrm{~mW} / \mathrm{cm}^{2}$ ) solar simulator as shown in Figure 5. Among the ten series of cells, the best initial conversion efficiency of $10.02 \%$ has been found with $V_{\mathrm{oc}}=0.88 \mathrm{~V}, J_{\mathrm{sc}}=$ $15.57 \mathrm{~mA} / \mathrm{cm}^{2}$, and $\mathrm{FF}=0.73$ for a cell area of $0.086 \mathrm{~cm}^{2}$. This initial efficiency is one of the highest recorded results to date for single-junction a-Si solar cells. The other recorded highest initial efficiencies of 10.1\% [2], 9.99\% [31], and 


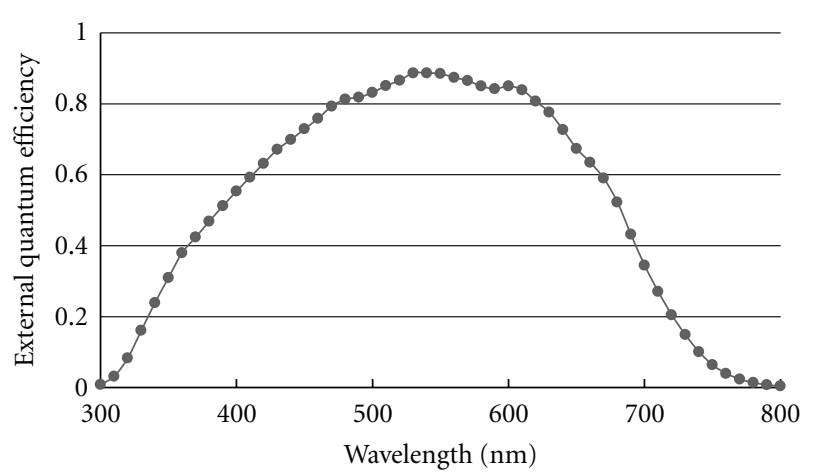

FIGURE 6: Quantum efficiency curve with wavelength in the range of $300-800 \mathrm{~nm}$.

9.3\% [32] have been found by different research groups. However, in this case, the validation of design optimization from numerical analysis has been proved to some extent.

The quantum efficiency (QE) measurement for $\mathrm{p}$-i-n single-junction a-Si:H solar cell has been performed to evaluate the spectral response as shown in Figure 6. The QE curve shows that the cell has a good spectral response in the wavelength range of $400 \mathrm{~nm}-650 \mathrm{~nm}$ and yields an AM1.5G integrated current density $J_{\mathrm{sc}}$ of $15.6 \mathrm{~mA} / \mathrm{cm}^{2}$ over the wavelength region from $300 \mathrm{~nm}$ to $800 \mathrm{~nm}$, which also promotes this to be a good candidate as a middle cell in triple-junction structure.

\section{Conclusion}

The single-junction a-Si:H solar cell has been designed numerically and finally fabricated to investigate the design validation for higher efficiency. The best efficiency of the numerically designed a-Si:H solar cell is $19.62 \%$ for i-layer thickness of $500 \mathrm{~nm}$ after optimizing the cell parameters. The temperature gradient for a-Si: $\mathrm{H}$ has been observed as $-0.23 \% /{ }^{\circ} \mathrm{C}$. The optimum bandgap for $\mathrm{a}-\mathrm{Si}: \mathrm{H}$ has been found to be $1.75 \mathrm{eV}$. The designed and optimized a-SiC:H/aSiC:H-buffer/a-Si:H/a-Si:H single-junction thin-film solar cells have been fabricated by PECVD. Among the series of ten single-junction a-Si:H cells, the best cell has an initial efficiency of $10.02 \%$ with $V_{\mathrm{oc}}=0.88 \mathrm{~V}, J_{\mathrm{sc}}=$ $15.57 \mathrm{~mA} / \mathrm{cm}^{2}$, and FF $=0.73\left(\right.$ area $\left.0.086 \mathrm{~cm}^{2}\right)$. This initial efficiency is one of the highest recorded results to date for single-junction a-Si solar cells. The QE curve shows that this cell has a good spectral response in the wavelength range of $400 \mathrm{~nm}-650 \mathrm{~nm}$ which means that it would be a good candidate as a middle component cell in triple-junction structure. All in all, the concept of numerical design prior to practical fabrication possesses the validation to a substantial extent toward achieving higher efficiency.

\section{Acknowledgments}

This work has been supported by the Department of Electrical, Electronic and System Engineering and Solar Energy Research Institute (SERI), UKM, Malaysia, through the research Grant UKM-GUP-BTT-07-29-184. The authors would also appreciate the cooperation of Professor Makoto Konagai's laboratory of Tokyo Institute of Technology, Japan.

\section{References}

[1] D. E. Carlson and C. R. Wronski, "Amorphous silicon solar cell," Applied Physics Letters, vol. 28, no. 11, pp. 671-673, 1976.

[2] U. Kroll, C. Bucher, S. Benagli et al., "High-efficiency p-i-n aSi:H solar cells with low boron cross-contamination prepared in a large-area single-chamber PECVD reactor," Thin Solid Films, vol. 451-452, pp. 525-530, 2004.

[3] M. I. Kabir, Z. Ibarahim, K. Sopian, and N. Amin, "A review on progress of amorphous and microcrystalline silicon thinfilm solar cells," Recent Patents on Electrical Engineering, vol. 4, no. 1, pp. 50-62, 2011.

[4] R. C. Chittick, J. H. Alexander, and H. F. Sterling, "The preparation and properties of amorphous silicon," Journal of the Electrochemical Society, vol. 116, no. 1, pp. 77-81, 1969.

[5] W. E. Spear and P. G. Le Comber, "Substitutional doping of amorphous silicon," Solid State Communications, vol. 17, no. 9, pp. 1193-1196, 1975.

[6] H. Aguas, S. K. Ram, A. Araujo et al., "Silicon thin film solar cells on commercial tiles," Energy \& Environmental Science, vol. 4, no. 11, pp. 4620-4632, 2011.

[7] A. Kołodziej, C. R. Wronski, P. Krewniak, and S. Nowak, "Silicon thin film multijunction solar cells," Opto-Electronics Review, vol. 8, no. 4, pp. 339-345, 2000.

[8] A. V. Shah, M. Vaněček, J. Meier et al., "Basic efficiency limits, recent experimental results and novel light-trapping schemes in a-Si:H, $\mu \mathrm{c}-\mathrm{Si}: \mathrm{H}$ and "micromorph tandem" solar cells," Journal of Non-Crystalline Solids, vol. 338-340, no. 1, pp. 639645, 2004.

[9] J. Meier, R. Flückiger, H. Keppner, and A. Shah, "Complete microcrystalline $\mathrm{p}-\mathrm{i}-\mathrm{n}$ solar cell—crystalline or amorphous cell behavior," Applied Physics Letters, vol. 65, no. 7, pp. 860862, 1994.

[10] J. Meier, S. Dubail, J. Cuperus et al., "Recent progress in micromorph solar cells," Journal of Non-Crystalline Solids, vol. 227-230, no. 2, pp. 1250-1256, 1998.

[11] L. Castens, J. Bailat, S. Benagli et al., "Advanced light management in Micromorph solar cells," in Inorganic and Nanostructured Photovoltaics-Symposium B at the E-MRS 2009 Spring Meeting, pp. 35-39, June 2009.

[12] K. Saito, M. Sano, S. Okabe, S. Sugiyama, and K. Ogawa, "Microcrystalline silicon solar cells fabricated by VHF plasma CVD method," Solar Energy Materials and Solar Cells, vol. 86, no. 4, pp. 565-575, 2005.

[13] X. Liao, W. Du, X. Yang et al., "Nanostructure in the p-layer and its impacts on amorphous silicon solar cells," Journal of Non-Crystalline Solids, vol. 352, no. 9-20, pp. 1841-1846, 2006.

[14] T. Wada, M. Kondo, and A. Matsuda, "Improvement of Voc using carbon added microcrystalline Si p-layer in microcrystalline Si solar cells," Solar Energy Materials and Solar Cells, vol. 74, no. 1-4, pp. 533-538, 2002.

[15] S. V. FonAsh, J. Arch, J. Cuiffi et al., A manual for AMPS$1 \mathrm{D}$ for Windows 95/NT, A one-dimensional device simulation program for the analysis of microelectronic and photonic structures, Pennsylvania State University, USA, 1997.

[16] T. Itoh, K. Fukunaga, Y. Katoh, T. Fujiwara, and S. Nonomura, "Doping of a-SiCX:H films including $\mu \mathrm{c}-\mathrm{Si}: \mathrm{H}$ by hot-wire 
CVD and their application as a wide gap window for heterojunction solar cells," Solar Energy Materials and Solar Cells, vol. 74, no. 1-4, pp. 379-385, 2002.

[17] N. Amin, M. I. Kabir, N. R. Hamzah, Z. Ibarahim, and K. Sopian, Effect of hydrogenated microcrystalline silicon oxide (ìc-SiO:H) in amorphous Si based thin film solar cells, World Renewable Energy Congress XI, (WREC), Abu Dhabi, UAE, 2010.

[18] K. Hayashi, M. Kondo, A. Ishikawa, and H. Yamagishi, "ZnO/Ag sputtering deposition on a-Si solar cells," in Proceedings of the World Conference on Photovoltaic Energy Conversion (WCPEC I '94), pp. 674-677, Honolulu, Hawaii, USA, 1994.

[19] Y. Hamakawa, H. Okamoto, and Y. Nitta, "Horizontally multilayered a-Si photo-voltaic cells A new type of high voltage photo-voltaic device," Journal of Non-Crystalline Solids, vol. 35-36, no. 2, pp. 749-754, 1980.

[20] M. I. Kabir, Z. Ibrahim, K. Sopian, and N. Amin, "Effect of structural variations in amorphous silicon based single and multi-junction solar cells from numerical analysis," Solar Energy Materials and Solar Cells, vol. 94, no. 9, pp. 1542-1545, 2010.

[21] S. Y. Myong, S. S. Kim, and K. S. Lim, "Improvement of pintype amorphous silicon solar cell performance by employing double silicon-carbide p-layer structure," Journal of Applied Physics, vol. 95, no. 3, pp. 1525-1530, 2004.

[22] M. J. M. Pathak, K. Girotra, S. J. Harrison, and J. M. Pearce, "The effect of hybrid photovoltaic thermal device operating conditions on intrinsic layer thickness optimization of hydrogenated amorphous silicon solar cells," Solar Energy, vol. 86, pp. 2673-2677, 2012.

[23] D. Lundszien, F. Finger, and H. Wagner, "A-Si:H buffer in aSiGe:H solar cells," Solar Energy Materials and Solar Cells, vol. 74, no. 1-4, pp. 365-372, 2002.

[24] B. Rech and H. Wagner, "Potential of amorphous silicon for solar cells," Applied Physics A, vol. 69, no. 2, pp. 155-167, 1999.

[25] J. Meier, S. Dubail, J. Cuperus et al., "Recent progress in micromorph solar cells," Journal of Non-Crystalline Solids, vol. 227-230, no. 2, pp. 1250-1256, 1998.

[26] M. Nawaz and A. Ashfaq Ahmad, "Influence of absorber doping in a-SiC:H/a-Si:H/a-SiGe:H solar cells," Journal of Semiconductors, vol. 33, no. 4, pp. 042001-042006, 2012.

[27] P. Singh, S. N. Singh, M. Lal, and M. Husain, "Temperature dependence of I-V characteristics and performance parameters of silicon solar cell," Solar Energy Materials and Solar Cells, vol. 92, no. 12, pp. 1611-1616, 2008.

[28] T. Trupke, M. A. Green, P. Würfel et al., "Temperature dependence of the radiative recombination coefficient of intrinsic crystalline silicon," Journal of Applied Physics, vol. 94, no. 8, pp. 4930-4937, 2003.

[29] M. A. Green, "General temperature dependence of solar cell performance and implications for device modelling," Progress in Photovoltaics: Research and Applications, vol. 11, no. 5, pp. 333-340, 2003.

[30] D. L. Staebler and C. R. Wronski, "Reversible conductivity changes in discharge-produced amorphous Si," Applied Physics Letters, vol. 31, no. 4, pp. 292-294, 1977.

[31] X. Cao, W. Du, Y. Ishikawa, X. Liao, R. W. Collins, and X. Deng, "Fabrication and optimization of a-Si:H n-i-p single-junction solar cells with $8 \AA / s$ intrinsic layers of protocrystalline Si:H materials," in Materials Research Society Symposium Proceedings, pp. 365-370, April 2007.

[32] S. Sheng, Y. K. Chae, L. Li, J. Su, and X. Yang, "Scaling PECVD for large-area solar cells," in Applied Materials, Semiconductor International, Santa Clara, Calif, USA, 2008. 


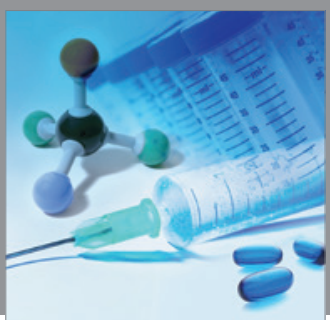

International Journal of

Medicinal Chemistry

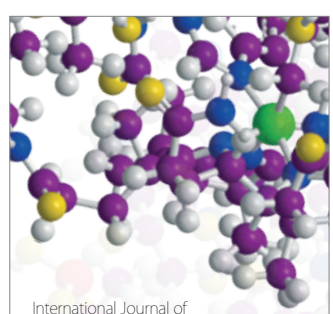

Carbohydrate Chemistry

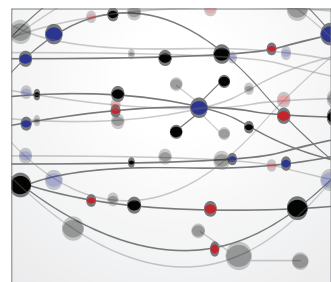

The Scientific World Journal
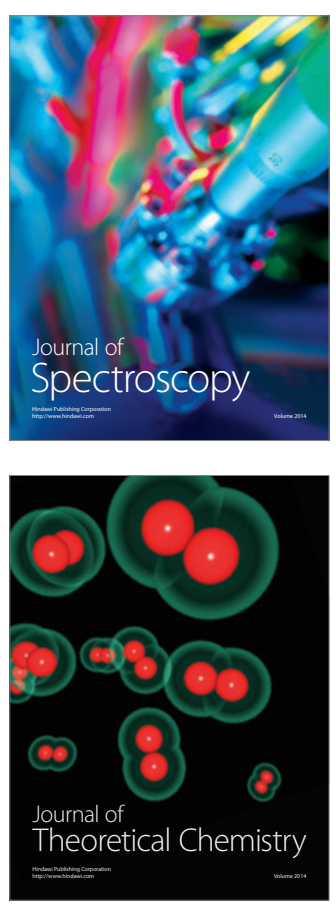
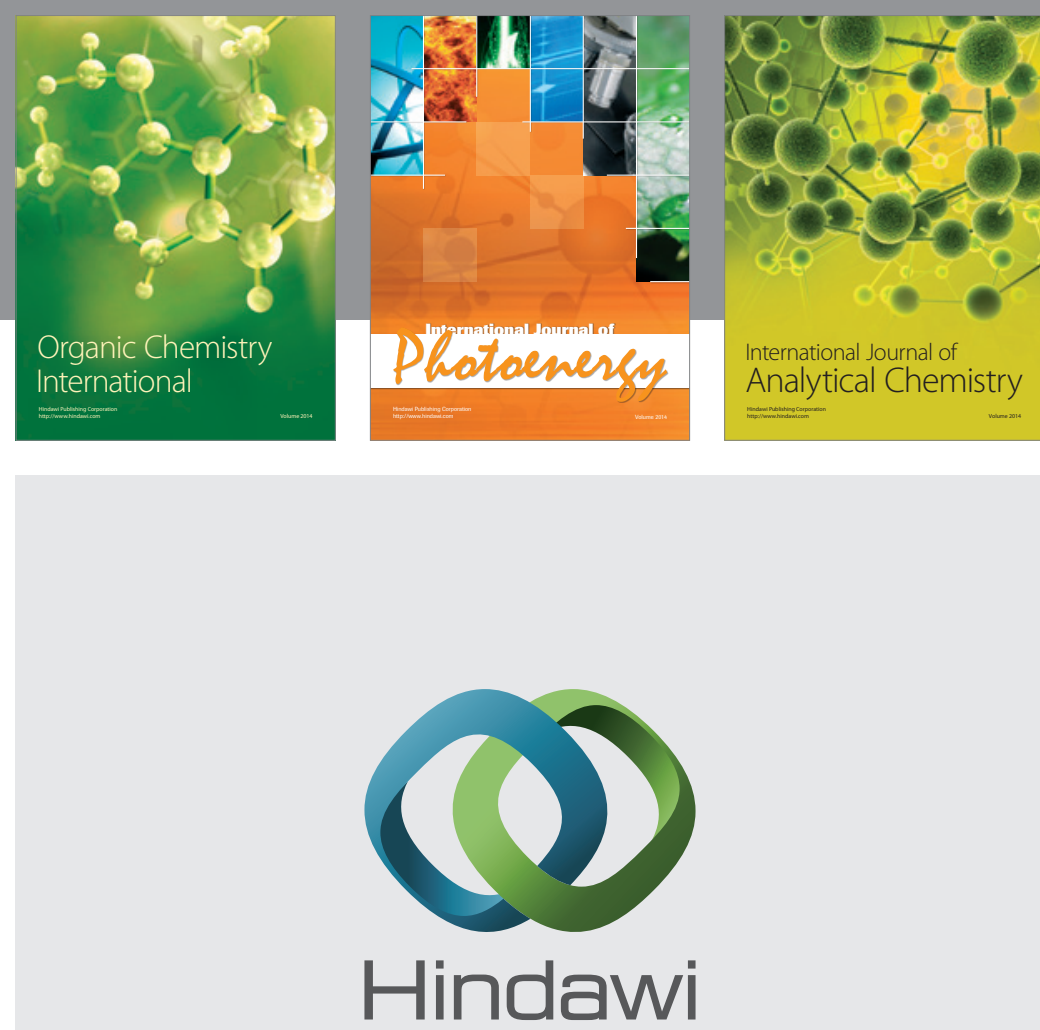

Submit your manuscripts at

http://www.hindawi.com
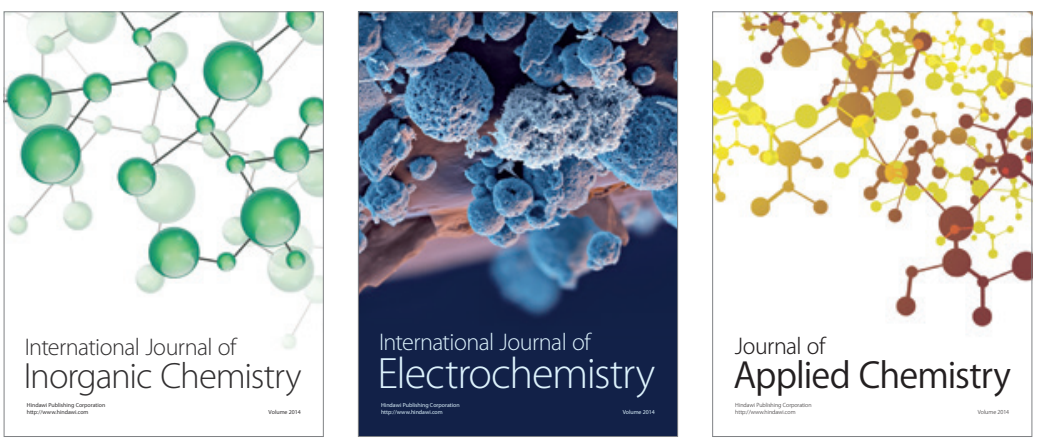

Journal of

Applied Chemistry
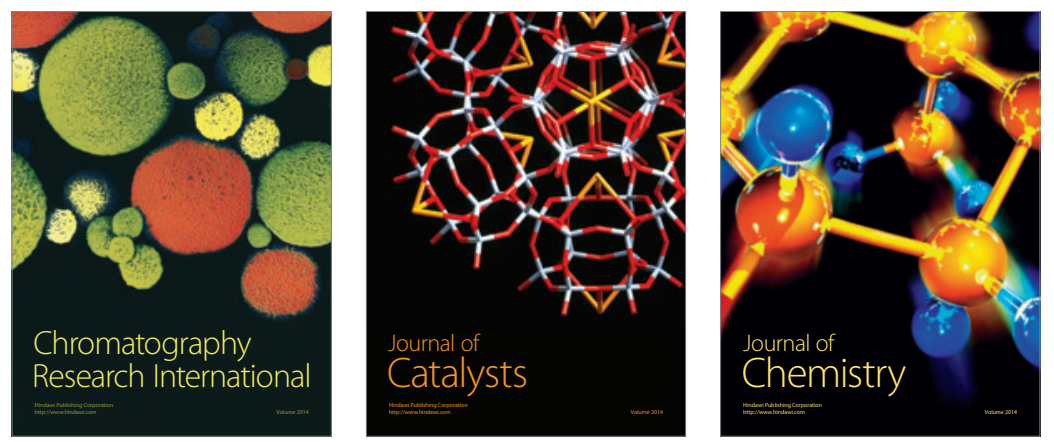
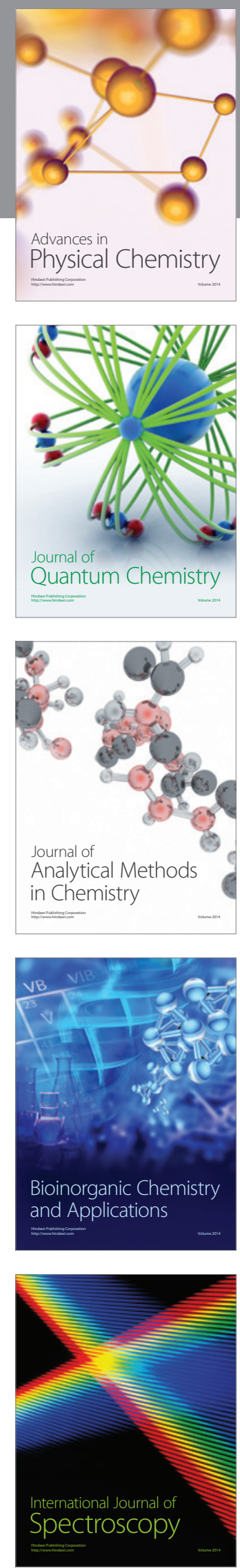